\title{
Exploration and Practice of Ideological and Political Education in College Curriculum in Veterinary Microbiology Teaching
}

\author{
Lianrui Li* \\ College of Animal Science, Tarim University, 843300, China. \\ E-mail: Lilianrui51@163.com \\ Subject: Curriculum ideological and Political Education of Molecular immunology (2902008) \\ Key course of Veterinary Microbiology (220101429) \\ Abstract: Veterinary microbiology is a very important course in the specialty of animal medicine. If curriculum ideol- \\ ogy and politics are applied to the teaching of veterinary microbiology, the teaching effect of veterinary microbiology \\ can be effectively improved. This aper mainly discusses the important role of ideological and political education in \\ the teaching of veterinary microbiology and how to fully explore the value of ideological and political education in the \\ teaching of veterinary microbiology.
}

Keywords: Curriculum Ideology and Politics; VeterinaryMicroorganisms; Practice

\section{Introduction}

In recent years, China's higher education develops rapidly, and the courses offered by universities are more and more diversified. However, for a long time, ideological and political courses in universities are mostly isolated, and ideological and political education is very important in higher education. Veterinary microbiology is one of the compulsory courses in animal medicine. Adding ideological and political education into the teaching course can make students better understand the main content of veterinary microbiology andplay a crucial role in cultivating students' innovative thinking ability. The teacher should focus on the ideological course of veterinary microbiology teaching [1].

\section{Exploration of the Necessity of Ideological and Political Courses in Veterinary Microbiology Teaching}

At present, colleges and universities have carried out the reform of curriculum ideological and political education. However, there are still some problems to be solved in the process of curriculum ideological and political education reform. We should grasp the key of curriculum ideological and political construction to carry out the reform, so as to make curriculum ideological and political education play its maximum value. From the perspective of long-term development, institutions of higher learning should combine "ideological and political courses" with "ideological and political education", so as to comprehensively improve the overall quality of students and cultivate qualified talents for socialist construction.

\subsection{Requirements of national legal documents and educational policies on curriculum ideology and politics}

Teachers' law of the People's Republic of China clearly points out that the primary responsibility of teachers is to teach and educate people, to train qualified successors for the socialist modernization and to improve the basic quality of citizens. Therefore, teachers should take teaching as their mission. On the one hand, teachers should impart knowledge

Copyright (C) 2020 Lianrui Li

doi: $10.18282 /$ le.v9i6.1317

This is an open-access article distributed under the terms of the Creative Commons Attribution Non-Commercial License

(http://creativecommons.org/licenses/by-nc/4.0/), which permits unrestricted non-commercial use, distribution, and reproduction in any medium, provided the original work is properly cited. 
to students, on the other hand, they should also pay attention to moral education, especially the education of socialist core values. At present, colleges and universities follow the educational concept of combining various courses with ideological and political theory courses, give full play to the important role of ideological and political education, and explore the teaching model of "ideological and political courses".

Colleges and universities pay more attention to the reasonable arrangement of courses, better integrate ideological and political courses into the veterinary microbiology major, and carry out ideological and moral education for students. These practices reflected that relevant education departments in colleges and universities attached importance to ideological and political education work. It also requires schools to follow the core of education "courses" education idea and to set "strengthen moral education and cultivate people" as a fundamental goal of teaching. Teachers should take teaching as fundamental tasks and carry out ideological and political education in all courses in colleges and universities [2].

\subsection{Give full play to the advantages of ideological and political courses to cultivate talents}

At present, China's higher education has made rapid development, and the number of college graduates is also increasing, so it is very important to do a good job in ideological and political education of college students. On the one hand, we should adhere to the ideological and political education through the entire university education, and the education workers in colleges and universities should fully realize the importance of ideological and political education for the cultivation of talents, which is not only political cadres at universities can realize its importance, but also teachers want to undertake to the student ideological and political education. Teachersset improving students' moral level and political literacy as the main task, and raise students' professional skills and veterinary microbiology. On the other hand, it is necessary to carry out educational pilot reform in colleges and universities, to integrate ideological and political courses into the curriculum system of colleges and universities, and to constantly explore new approaches to ideological and political education.

\subsection{Explicit education and implicit education can be integrated}

The particularity of ideological and political course lies in its combination of "implicit course" and "explicit course". In this process, the reform of higher education should be continuously deepened, and the thought of education reform should be incorporated into the curriculum construction. The educational reform of curriculum ideology and politics should be constantly innovated and explored, so as to explore a new development model. It is not only necessary to introduce the new development plan of curriculum ideology and politics into the moral education work of school-level leaders, but also to integrate the ideological and political curriculum resources into the talent training program [3].

The development of "Course Ideology and Politics" is not to set up a single course or add a training activity, but to integrate it into all professional courses, and to integrate relevant contents of ideological and political education into each major. Moral education is invisible, while ideological and political education is explicit. By combining the two, students can improve their moral quality invisibly and promote the development of their comprehensive quality.

\section{Exploration and Practical Analysis of Curriculum Ideology and Politics in Veterinary Microbiology Teaching}

\subsection{Update the teaching contents of veterinary microbiology and cultivate students' innovative spirit}

Veterinary microbiology teaching requires teachers to teach students the basic curriculum knowledge and practical skills on the one hand.On the other hand, teachers should focus on the latest development of disciplines and the latest research results, combine with the latest research results and theory in the classroom teaching, update teaching content, stimulate student's study enthusiasm and enhance their learning motivation, cultivate students' innovative thinking and innovative ability, improve the students' interest in learning and stimulate the curiosity of students in scientific exploration[4].

\subsection{Respecting the teaching law of veterinary microbiologyas the premise}

The construction and development of curriculum ideology and politics aim at improving students' moral level and realizing the goal of education better. But different professional courses have different characteristics, the nature of the subject, teaching content and teaching methods are not the same. In terms of education, different disciplines play 
different roles. For example, humanities and social sciences courses mainly help students to understand the law of the development of human society, help students to establish a correct world view, outlook on life and values; But natural science pays attention to train the student to explore the spirit of science, helps the student to set up the great ideal and inspiresstudents to have the sense of responsibility and the mission. Therefore, the specialized courses of different subjects cannot be taught in a unified mode, which is not in line with the development goal of ideological and political construction[5].

Different professional courses have different teaching methods and processes. It is not to simply integrate the course ideology and politics into the professional curriculum, which is against the original intention of the course ideology and politics construction. It is necessary to analyze the course characteristics of veterinary microbiology, integrate ideological and political education into the course contents and curriculum planning, and conduct teaching and curriculum planning according to the characteristics of different students[6].

\subsection{Adapting to the content of veterinary microbiology course and designing the course}

It is necessary to design and plan the curriculum in detail for the construction and development of curriculum ideology and politics, whichincludes teaching objectives, teaching content, and teaching methods and so on. The perfect curriculum design system can make the teaching effect better. Teachers of veterinary microbiology should take the characteristics and advantages of the subject into full consideration in the course design, combine the teaching contents in the teaching process to improve students' moral quality, and combine the two to avoid isolating or formalizing the ideological and political teaching of the course[7]. For example, in the teaching design, on the one hand, we should construct the knowledge system; on the other hand, we should also pay attention to the cultivation of students' values.

When designing "knowledge module", we should combine the contents of values and fully explore the ideological and moral concepts contained in the knowledge system from different perspectives. We can also integrate the contents of the value modules with each other to bring them to each other. Meanwhile, we can integrate the ideological and political contents of values from point to point to form a complete value system. At the same time, we can integrate the professional knowledge of disciplines to make it cooperate and promote each other.

\section{Conclusion}

At present, colleges and universities are actively innovating new methods of ideological and political education. Colleges and universities have integrated ideological and political education into the teaching of veterinary microbiology with the fundamental teaching goal of cultivating people through virtue, and have been striving to solve various problems existing in the course teaching. Colleges and universities should discover ideological and political education content in veterinary microbiology course, play its educational value, and break the previous mode of relying on ideological and political course to improve students' moral quality of traditional limitations. The veterinary microbiology course should be combined with ideological and political course, so as to promote the development of students' comprehensive quality, achieve the goal of strengthening moral education and cultivating people.

\section{References}

1. Martineau R. Curriculum Politics Says [J]. Journal of RSA Journal, 1993, 141 (5438): 325-326.

2. GF Browning. Clinical Veterinary Microbiology [J]. Australian Veterinary Journal, 1995, 72 (6): 239-239.

3. Baltimore, David. Molecular Immunology: Growth into Bonds [J]. Trends in Biochemical Sciences, 1984, 9 (4): 137138.

4. Ming Ming, Zhou Bijun, Cheng Zhentao, Xian Simei, Wen Guilan. Reform of Veterinary Microbiology Curriculum to Cultivate Students' Innovative Thinking Ability [J]. Heilongjiang Animal Husbandry and Veterinary Science, 2014, (05): 170-171.

5. wang lingzhi, huang jie. A preliminary study on the practice of "curriculum ideology and politics" construction in colleges and universities [J]. Journal of science and technology, 2019, (35) : 65+68.

6. peng renfu. Analysis on ideological attributes of ideological politics in college curriculum [J]. Agricultural mechanization of hubei province, 2019, (23) : 104-105.

7. Yang yu, lu yan. Exploration and innovation of experimental teaching of veterinary microbiology [J]. Animal husbandry and veterinary medicine, 2008, $50(08): 126-128$. 